\title{
The Potential of Long-Acting, Tissue-Targeted Synthetic Nanotherapy for Delivery of Antiviral Therapy Against HIV Infection
}

\author{
Anna Halling Folkmar Andersen 1,2,*(D) and Martin Tolstrup 1,2 \\ Department of Infectious Diseases, Aarhus University Hospital, 8200 Aarhus, Denmark; mtol@clin.au.dk \\ 2 Department of Clinical Medicine, Aarhus University, 8000 Aarhus, Denmark \\ * Correspondence: ahfa@clin.au.dk
}

Received: 3 March 2020; Accepted: 1 April 2020; Published: 7 April 2020

check for updates

\begin{abstract}
Oral administration of a combination of two or three antiretroviral drugs (cART) has transformed HIV from a life-threatening disease to a manageable infection. However, as the discontinuation of therapy leads to virus rebound in plasma within weeks, it is evident that, despite daily pill intake, the treatment is unable to clear the infection from the body. Furthermore, as cART drugs exhibit a much lower concentration in key HIV residual tissues, such as the brain and lymph nodes, there is a rationale for the development of drugs with enhanced tissue penetration. In addition, the treatment, with combinations of multiple different antiviral drugs that display different pharmacokinetic profiles, requires a strict dosing regimen to avoid the emergence of drug-resistant viral strains. An intriguing opportunity lies within the development of long-acting, synthetic scaffolds for delivering CART. These scaffolds can be designed with the goal to reduce the frequency of dosing and furthermore, hold the possibility of potential targeting to key HIV residual sites. Moreover, the synthesis of combinations of therapy as one molecule could unify the pharmacokinetic profiles of different antiviral drugs, thereby eliminating the consequences of sub-therapeutic concentrations. This review discusses the recent progress in the development of long-acting and tissue-targeted therapies against HIV for the delivery of direct antivirals, and examines how such developments fit in the context of exploring HIV cure strategies.
\end{abstract}

Keywords: HIV; drug delivery; antiretroviral therapy; HIV reservoir; nanotherapy

\section{Introduction}

Combination antiretroviral therapy (cART) has transformed HIV from a life-threatening disease to a manageable infection. Treatment-adherent individuals with full viral suppression can live healthy, long lives and are unable to transmit the virus to others. Yet, in 2018, there were still approximately 770,000 AIDS-related deaths and 1.7 million people became infected with HIV [1]. Even though antiretroviral drugs (ARVs) have the ability to decrease plasma viral load to below detection, these drugs are not able to clear all viruses from the host. It is therefore evident that despite huge success in the development of treatment and prevention, a cure is still warranted.

The formation of latent viral reservoirs that persist despite having none to very limited viral replication prevents a successful cure with suppressive cART. These viral reservoirs can be defined on the basis of the cells that are infected e.g., infected T- or myeloid cells, or the anatomical sites such as lymph nodes (LN), central nervous system or gut-associated lymphoid tissues (GALT), where these cells reside [2]. A recent report from studies of simian immunodeficiency virus (SIV)-infected macaques suggests that $98.6 \%$ of SIV vRNA+ cells reside in lymphatic tissues (i.e., LNs, spleen, GALT) [3].

The particular biology of infected cells and limited tissue penetration of ARVs in concurrence may cause the presence of a viral reservoir [4-6]. Independent of mechanism, a cure for HIV would 
entail targeting the major sites where these viral reservoirs persist. The "shock and kill" approach is one of the strategies pursued to achieve an HIV cure. An important component of this approach is the use of a latency-reversing agent (LRA) that shocks the virus into a more active form. Consequently, the activated virus would then be rendered susceptible for clearance by the immune system [7].

In most cases, a cure approach would be accompanied by cART to prevent the infection of new cells. Many of the compounds available today suffer from short half-lives and limited tissue penetrations, which consequently could impede their activity at the most relevant viral reservoir sites [8]. Moving forward, it may be of importance to study and optimize both existing and newly developed ARVs as well as the components of HIV cure treatments for enhanced viral reservoir targeting/penetrance.

This review discusses the potential of long-acting, tissue-targeting synthetic scaffolds that enable delivery of cART and HIV cure agents to HIV-burdened lymphatic tissues. Please refer to other excellent reviews for details on the penetration of nanotherapeutics into the central nervous system $[9,10]$. Particularly, this review will focus on how features from nanotechnology can aid in overcoming some of the key challenges faced by both cART and HIV cure strategies, including low bioavailability, low tissue penetration in lymphatic tissues and short plasma half-lives.

\section{State of the ART}

Strict adherence and continuous viral monitoring have conditioned HIV+ people to live long lives. The current treatment consists of a set combination of two or three ARVs that must be administered daily. Because of the high mutation rate of the HIV genome during viral replication, monotherapy quickly results in the emergence of drug-resistant viral strains and treatment failure. Inhibiting multiple different enzymes and blocking important host-virus interactions in the viral life cycle are key to fully block viral replication and prevent resistance development. However, upon cessation of cART, the virus will rebound and become detectable in plasma typically within weeks [11]. Several classes of antiretroviral drugs have been developed and are grouped based on which step of the HIV replication cycle they inhibit. Overall, the different drug classes are: (1) nucleoside and non-nucleoside reverse transcriptase inhibitors (NRTIs and NNRTIs, respectively), (2) protease inhibitors (PIs), (3) fusion inhibitors, (4) entry inhibitors and (5) integrase inhibitors (INIs) [12]. The different currently marketed pharmaceuticals are presented in Table 1 . To fully comprehend what determines the dose effectiveness of treatment, one needs to understand the sequential barriers and sites of loss that orally administered antiretrovirals face before exerting their intended antiretroviral function. This following section will elucidate the path from administration to cellular function of current ARVs.

Table 1. FDA-approved pharmaceuticals for HIV treatment of HIV infection.

\begin{tabular}{|c|c|c|c|}
\hline Drug Class & Name (Acronym) & $\begin{array}{l}\text { Plasma }_{\frac{1}{2}} \text { in } \\
\text { Humans (h) }\end{array}$ & $\begin{array}{c}\text { Absolute } \\
\text { Bioavailability }\left(\mathrm{F}_{\mathrm{abs}}\right)\end{array}$ \\
\hline \multirow{8}{*}{$\begin{array}{l}\text { Nucleoside/nucleotide } \\
\text { reverse transcriptase } \\
\text { inhibitor (NRTIs) }\end{array}$} & Zidovudine (ZDV/AZT) [13] & 1.2 & $60-70 \%$ \\
\hline & Didanosine (DDI) [14] & 1.5 & $25-43 \%$ \\
\hline & Stavudine (d4T) [15] & 1.6 & $82-99 \%$ \\
\hline & Lamivudine (3TC) $[16,17]$ & 5.4 & $86-88 \%$ \\
\hline & Abacavir (ABC) [18] & 1.3 & $83 \%$ \\
\hline & Tenofovir disoproxil fumarate (TDF) [19] & 18.3 & $\begin{array}{c}25 \% \text { in fasting, } \\
\text { increased with food }\end{array}$ \\
\hline & Tenofovir alafenamide (TAF) [20] & 51.3 & $\mathrm{n} / \mathrm{a}$ \\
\hline & Emtricitabine (FTC) [21] & 4.8 & $\sim 100 \%$ \\
\hline
\end{tabular}


Table 1. Cont.

\begin{tabular}{|c|c|c|c|}
\hline Drug Class & Name (Acronym) & $\begin{array}{l}\text { Plasma } T_{\frac{1}{2}} \text { in } \\
\text { Humans (h) }\end{array}$ & $\begin{array}{c}\text { Absolute } \\
\text { Bioavailability }\left(\mathrm{F}_{\text {abs }}\right)\end{array}$ \\
\hline \multirow{5}{*}{$\begin{array}{l}\text { Non-nucleoside reverse } \\
\text { transcriptase inhibitors } \\
\text { (NNRTIs) }\end{array}$} & Efavirenz (EFV) [22] & 37.7 & $\sim 100 \%$ \\
\hline & Nevirapine (NVP) [23-26] & 21.5 & $90-93 \%$ \\
\hline & Extended-release NVP [27] & 45 & $\mathrm{n} / \mathrm{a}$ \\
\hline & Etravirine (ETR) $[28,29]$ & $30-50$ & $\mathrm{n} / \mathrm{a}$ \\
\hline & Rilpivirine (RPV) [30] & 48 & $\mathrm{n} / \mathrm{a}$ \\
\hline \multirow{10}{*}{ Protease inhibitors (PIs) } & Saquinavir (SQV) [31] & 3.6 & $4-12 \%$ \\
\hline & Ritonavir (RTV) [32] & 3.5 & $60 \%$ \\
\hline & Indinavir (IDV) [33] & 1.8 & $\sim 100 \%$ \\
\hline & Nelfinavir (NFV) [31,34] & 4.3 & $\sim 100 \%$ \\
\hline & Lopinavir (LPV) [35] & $5-6$ & $\mathrm{n} / \mathrm{a}$ \\
\hline & Lopinavir (LPV) oral pellets & $5-6$ & $\mathrm{n} / \mathrm{a}$ \\
\hline & Fosamprenavir (FPV) [36] & 4.8 & $\mathrm{n} / \mathrm{a}$ \\
\hline & Atazanavir (ATV) [37] & 7.5 & Low \\
\hline & Tipranavir (TPV) [38] & 2.6 & $\mathrm{n} / \mathrm{a}$ \\
\hline & Darunavir (DRV) $[39,40]$ & 14.6 & $\begin{array}{l}37 \% \text { (w/o ritonavir) } \\
82 \% \text { (with ritonavir) }\end{array}$ \\
\hline Fusion inhibitors & Enfurvirtide (T-20) [41] & 2 & $\mathrm{n} / \mathrm{a}$ \\
\hline Entry inhibitors & Maraviroc (MVC) [42] & 23 & $23.1-33 \%$ \\
\hline \multirow{4}{*}{$\begin{array}{l}\text { Integrase inhibitors } \\
\text { (INIs) }\end{array}$} & Dolutegravir (DTG) $[43,44]$ & 13.5 & 87\% (in monkeys) \\
\hline & Elvitegravir (EVG) $[45,46]$ & 9.9 & $<25 \%$ \\
\hline & Raltegravir (RAL) [47] & 9.3 & $\mathrm{n} / \mathrm{a}$ \\
\hline & Bictegravir (BIC) [48] & 17.3 & $\mathrm{n} / \mathrm{a}$ \\
\hline
\end{tabular}

FDA-approved drugs for treatment of HIV infected are listed, including their biological target, year of approval, full name and acronym. Plasma half-lives after a single oral or intravenous dose are listed for each drug. The absolute bioavailability is listed where available and calculated based on the calculation: $F_{a b s}=100 \cdot \frac{A U C_{p o} \cdot D_{i v}}{A U C_{i v} \cdot D_{p o}}$. Note, the calculation of absolute bioavailability relies on data from studies done using intravenous administration, which are not available for many recent ARVs. ( $/ \mathrm{a}=$, not available). Adapted from $[49,50]$.

\section{Bioavailability and Pharmacokinetics}

The first challenge of orally administered drugs is absorption through the gut wall. Because many ARVs, particularly protease inhibitors, are poorly water-soluble, incomplete dissolution in the gut lumen decreases transfer across the intestine wall [51]. Consequently, a large fraction of the ingested compound never reaches systemic circulation, which is often the main factor for a low plasma bioavailability [52]. Table 1 lists the calculated bioavailability of different ARVs.

Once inside the lamina propria of the gut, a minor fraction of the drug will be drained by the lymph capillaries but the majority will be transported by blood vessels that drain the interstitial space to the portal vein that passes through the liver. The liver is responsible for the first-pass metabolism of many compounds, including ARVs. Thus, ARVs are partially metabolized and cleared from the blood system before even reaching systemic circulation. The fraction that does leave the liver intact goes through the vena porta to the heart and lung system before being dispersed into the arterial system. In this blood system, certain ARVs suffer from a short terminal plasma half-life $\left(\mathrm{T}_{\frac{1}{2}}\right)$ (listed in Table 1). Short plasma half-life is caused by a combination of multiple factors, including size and kidney excretion, and other physicochemical properties such as high hydrophobicity or high affinity for metabolizing enzymes in the liver. A particularly classic example is the PI, saquinavir, a very hydrophobic molecule with high substrate affinity for the efflux transporter P-glycoprotein (P-gp) and 
the hepatic enzyme, cytochrome P4505A (CYP3A). This results in efficient transport out of the cells and a rapid metabolism in the liver and subsequent excretion of saquinavir [53,54]. Consequently, the bioavailability of saquinavir following oral dosing is only $4 \%$ of the administered dose. Therefore, the clinical application of saquinavir is lower due to an increased risk of hepatic side effects at therapeutic doses [55]. These factors are accounted for in the dosing regimen; however, the risk of reaching sub-therapeutic concentrations with a missed or delayed dose is increased.

\section{Tissue Penetration}

The relatively high permeability of lymph capillaries in the peripheral tissues such as the lamina propria of the gut causes the lymph capillaries and lamina propria to be similar in composition on many parameters. However, ARVs can be excluded from entering the lymphatic system directly because the equilibrium between lymph and interstitial space is affected differently by physicochemical properties as well as a low flow rate in the draining lymph capillaries [4]. Properties of compounds that are associated with a higher degree of lymphatic uptake include higher molecular weight, higher overall particle size and higher lipophilicity [56-59]. The resulting limited tissue penetration of ARVs leads to sub-therapeutic concentrations in many important virological sites such as the lymphatic tissues, particularly the lymph nodes. Whether this can facilitate continuous low-level HIV replication in these tissues and contribute to the rapid rebound seen upon cessation of cART has been speculated $[6,60,61]$.

In summary, there are several major challenges associated with the current approved pharmaceuticals against HIV infection. The overall aim of rethinking cART and cure agents in the context of nanotherapeutics is to have the physicochemical properties of the drug delivery platform dictate the fate of the antivirals in vivo $[62,63]$.

\section{What are Nanotherapeutics for HIV Treatment and Cure?}

Combining antiretroviral drugs with a synthetic molecule can be an attractive approach to solve some of the inherent challenges with the small molecule drug itself. Because these synthetic compounds are typically in the 1-100 nanometer range, they are referred to as nanotherapeutics. Various types of nanotherapeutics have already been developed for other healthcare applications, particularly cancer therapy, where a compound such as PEG-lipidated Doxorubicin (Doxil [64]) is used as a first-line therapy against a range of solids tumors e.g., breast and ovarian cancer [65-67].

Many different classes of synthetic molecules have been utilized as the nanotherapeutic scaffold for antiretroviral drug delivery, including nanoparticles comprised of polymers, lipids, liposomes, micelles, dendrimers and inorganic particles, e.g., gold nanoparticles [68]. Protein-conjugates, such as antibody-drug conjugates or albumin-conjugated compounds are sometimes also included when discussing nanotherapeutic compounds. In the interest of limiting the scope, this review discusses classical examples of these different synthetic scaffolds. The major synthetic strategies and the commonly associated benefits and of these different approaches are detailed in Figure 1. Antibody drug-conjugates have been extensively used for targeting e.g., CD4 for anti-HIV applications. Here, cells that do not express the antibody target are bypassed, and only cells bearing the target are engaged. In principle, antibodies can be added to most nanotherapeutic molecules as a targeting moiety [69]. Inorganic nanoparticles can be constructed by e.g., gold or silver nanoparticles and can have beneficial properties for anti-HIV drug delivery [70]. They can be internalized in different cell types such as macrophages, which can be either a benefit or a caveat depending on whether these were the intended target [68]. Their typical smaller size (compared to other nanotherapeutics) facilitate entry into tissues such as the central nervous system but also distinct pharmacokinetic profiles. Lipid vesicles were the first nanomaterial utilized for drug delivery. Lipid vesicles are closed, self-assembling spheres comprised of a bilayer of phospholipids. The lipid bilayer surrounds an aqueous space, wherein drugs are enclosed. These molecules can vary greatly based on preparation, their overall lipid composition, size and surface charge, and all of these parameters can influence biological effects and pharmacokinetics. The particles interact with cell surfaces for their drug delivery, either through 
adsorption, fusion of membranes or endocytosis. Disadvantages to lipid vesicles include their limited drug-loading capacities of hydrophilic drugs [71]. Polymer and lipid nanoparticles are heterogeneous in composition, size and overall shape. They can be comprised of biostable or biodegradable monomers and can carry drug agents via one of several mechanisms: chemically linked to the particle; entrapped or encapsulated within the polymer-lipid particle; or adsorbed onto the particle surface via hydrophobic interactions [72,73]. Polymer micelles consist of a hydrophobic core and a hydrophilic shell, forming a spherical micelle. Similarly, to the lipid vesicles, these structures can transport cargo within the central core, or in/on the surface of the shell. In addition, the micelles can be modified to include targeting moiety or other ligands that enable more specific drug delivery [73]. Another benefit of polymer systems such as PEG is that the overall structure becomes "masked" from immune recognition by preventing opsonization [74]. Hydrogel, implants and suspensions are a heterogeneous class of drug delivery modalities spanning from simple saline suspensions of nanotherapeutic drugs to gels and implants. Examples are suspensions of otherwise poorly soluble drugs with stabilizers (i.e., a surfactant) into nano-sized crystals to improve the overall solubility. These solutions have slow dissolution, facilitating sustained release into the blood after e.g., subcutaneous or intramuscular drug delivery. One potential caveat of these crystals in solution is that once in plasma they can be rapidly phagocytosed by macrophages e.g., Kuppfer cells in the liver [75]. Other examples in this group are polymers formulated in gel-form for local topical application, e.g., for protection of mucus barriers during intercourse, and injected/implantable, degradable devices that release drugs over time [76]. Importantly, many nanotherapeutic systems are combinations of these different scaffold classes.

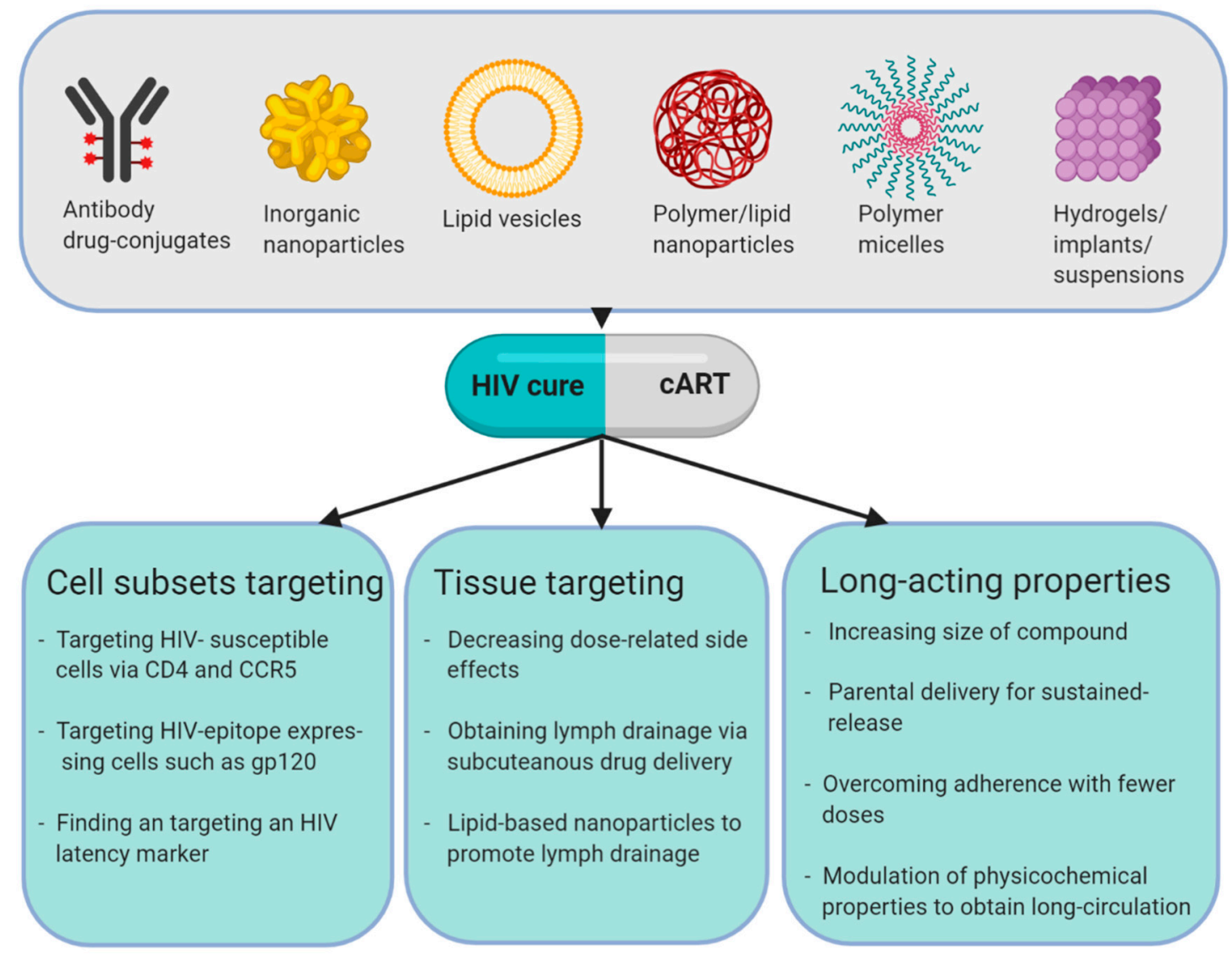

Figure 1. Examples of types of nanotherapy and their application in HIV treatment and cure. Created with Biorender.com. 
All of these compounds are relatively biologically inert structures able either to encapsulate or to carry small molecule drugs through direct covalent linkage. However, the physicochemical and biologic properties of the nanotherapeutics can be modulated by the addition of either polyanionic, hydrophobic or hydrophilic side chains on the scaffold. Moreover, the compound can be further modified by the addition of targeting ligands [49]. Indeed, the construction design of the lipid or polymer scaffold is virtually unlimited, but some practical considerations must be taken into account. For example, in many current spherical non-covalent nanoparticles of physiological relevant sizes, the pharmaceutical active drugs comprise only $1 \%$ of the total molecular weight [49].

\section{Long-acting Antiviral Prodrugs}

Less than daily administration of effective cART is eminent, and the terminology of long-acting is currently defined as less-than-daily dosing. This description covers both new formulations of small molecule drugs into long-acting oral formats and the field of nanotherapeutics. The latter is sometimes referred to as sustained-release, extended-release or controlled-release, but covers the same meaning: a novel compound, drug-delivery platform or formulation whose physicochemical properties ensures long-circulation and thus long-acting antiretroviral therapy. Much attention has been put on parental drug delivery over oral [76].

Currently, two phase III clinical trials are investigating intramuscular delivery of a polymer-based, long-acting formulation of cabotegravir and rilpivirine (ATLAS (NCT02951052) and FLAIR (NCT02938520) [77]. The plasma half-life of the integrase inhibitor cabotegravir is $40 \mathrm{~h}$ after oral administration [78] and rilpivirine, an NNRTI, halves in $48 \mathrm{~h}$. This combination has promising use as a once-monthly maintenance therapy after an oral lead-in phase. Despite the therapy being well tolerated, the US FDA declined the approval of this treatment regimen in December 2019. The reasons for rejection were regarding chemistry, manufacturing and controls (CMC) [77-79].

Other preclinical studies aiming to identify long-acting small anti-HIV molecules have been published. For example, Yant et al. identified a novel, potent capsid inhibitor, GS-CA1 displaying a long plasma half-life after subcutaneous (s.c.) delivery [80]. Because this compound is highly insoluble in water, it relies on the slow diffusion from the initial depot injection in the interstitial space for sustained activity. However, despite impressive half-life data and high anti-viral efficacy, no evidence of improved drug-delivery to HIV reservoirs was given and the drug was not tested as part of a cART regimen [80].

Increasing the size of a molecule by use of a synthetic polymer scaffold is another approach to extend its overall plasma half-life, caused by a size-dependent retention by the kidney excretion system. This is easily obtainable via nanotherapeutic approaches. Recent progress in polymer production strategies has enabled polymer synthesis to become a tightly controlled process, where polymer structures with low polydispersity can be created. Previously, polymer nanotherapeutics were impeded by unacceptable batch-to-batch variations as well as within-batch size heterogeneity. Combined with novel linker chemistry, for example self-immolative linkers (SIL), both polymer size and complexity as well as triggered release of drug can be controlled, yielding a very attractive drug-delivery strategy [81]. Some of the most commonly used polymer systems are poly(hydroxypropyl methacrylamide) (PHPMA) [82-87], poly(lactic-co-glycolic acid) (PLGA) [88], poly(methacrylates) (PMA) $[89,90]$ and poly(ethylene glycol) (PEG) [91]. The benefit of combining direct conjugation to a polymer via linker chemistry is the possibility to co-deliver different pharmaceutical drugs on the same polymer scaffold. This type of design thus enables combination therapy with precise drug ratios that are specifically released upon intracellular stimuli-highly appealing for cART, potentially in combination with an HIV cure agent.

Our group sought to develop and utilize these features of polymers. We have focused on combining antiviral small molecule drugs with synthetic polymers in combination with lipids such as DSPE or endogenous proteins like albumin to develop long-acting drug-delivery platforms [81-87,92]. Because albumin has an incredible long circulation time in vivo in humans (i.e., 19-21 days [93]), it can 
be used to traffic compounds through circulation. However, direct albumin-drug conjugation can be complicated by both formulation, biocompatibility and storage challenges. Using a lipid-polymer, such as 1,2-distearoyl-sn-glycero-3-phosphoethanolamine poly(ethylene glycol) (DSPE-PEG) with a natural affinity for albumin in vivo can solve this [94,95]. Upon administration, the lipid will quickly bind to albumin and become trafficked by the protein through the body. Synthetic polymers such as PEG serve as the linker between the small molecule drug and the lipid [81].

Li et al. developed a structure based on a biodegradable nanoparticle of PEG-PLA (poly(ethylene glycol)-poly(lactic acid)) that encapsulated an HIV fusion inhibitor, T1144, and an experimental NNRTI, DAAN-14f. The compound displayed an improved pharmacokinetic profile over pristine drugs in rats after intravenous dosing without loss of anti-HIV efficacy in vitro [96]. Mandal et al. pursued a similar strategy with nanoparticles of PLGA encapsulating elvitegravir (EVG), emtricitabine (FTC) and tenofovir alafenamide (TAF), and found that this combination had HIV prevention effects in humanized mice [97-99].

Long-acting or sustained-release formulations can also be obtaining by utilizing the phagocytic features of monocyte-macrophages as a reservoir for nanoparticles [100,101]. After cellular uptake, these particles will slowly degrade and thus release ARVs. Recently, an interesting strategy was developed comprising a "long-acting-, slow-effective release antiretroviral therapy" strategy (Laser ART) that enabled delivery of ARVs such as dolutegravir, lamivudine, abacavir and rilpivirine encapsulated in lipid nanoparticles via myristoylation. The result was hydrophobic, lipophilic "nanocrystals", which were non-specifically internalized into monocytes and macrophages, and slowly released to the surrounding extracellular space [102-105]. Interestingly, two out of seven humanized HIV-infected mice were cured when Laser ART was combined with CRISPR/Cas9-mediated excision of HIV DNA [106]. These mice did not have detectable HIV in blood, lymphoid tissues, bone marrow, spleen or brain five weeks after end of therapy.

In summary, these studies prove that using nanotherapeutic formulation techniques, it is possible to develop compounds that challenge the "once-daily"-paradigm. However, issues remain regarding the depot in case of adverse events, since stopping therapy and removing the compound from the body can pose a significant hurdle or even be impossible.

\section{Increasing Access of Drugs to Lymphoid Tissues}

Nanotherapeutics have proven particularly useful within cancer research, where the enhanced permeability and retention (EPR) effect facilitates large molecules to passively target tissues with higher blood supply and metabolism, such as solid tumors [107]. Despite this simple assumption not being directly translatable to HIV-burdened tissues, the knowledge acquired from the development of the technology can be applied. The lymph nodes are less permeable for cART than other tissues which means that the concentration of cART is lower in these tissues than in the peripheral blood [4]. Increasing drug penetration using nanotherapeutic compounds could help decrease the risk of de novo cell infections and potentially improve the potency of new HIV cures aiming to clear or control these viral reservoir tissues.

Access to the lymphatic system can be approached at different levels: Overall specific drug delivery to a target can be executed at either the level of the whole tissue or at the cellular level [108]. The term "targeting" dictates that a drug targets a specific molecule or specific biological pathway (e.g., CD4-targeting). The term "localization" specifies a drug with properties that enable higher concentration in a biological tissue due to either specific or unspecific properties.

Delivering drugs more directly to the HIV reservoirs would be of highest relevance. Because the peripheral lymph system is a one-way system for fluid and protein drainage from the interstitial space, subcutaneous drug delivery and via the lymph system could be of use to reach HIV lymphatic reservoirs.

So why are ARVs not administered subcutaneously similar to e.g., insulin? The lymph system drains directly into the systemic circulation, so slow release into the blood stream could be achieved, 
and decreased bioavailability caused by impaired mucosal uptake avoided. Delivery of ARVs through the lymphatic system would also benefit from bypassing first-pass elimination in the liver [56].

Indeed, the initial lymph capillaries have free permeability to small molecules and these can thus diffuse unhindered through the initial lymph drainage system [63]. This causes the protein composition of intestinal fluids and lymph to be almost identical. Most of the fluid that will initially enter the lymph capillaries is resorbed in post-capillary venules and only larger molecules are retained in the lymph capillaries. The majority of molecules smaller than $10 \mathrm{~nm}$ such as ARVs are preferably absorbed from the interstitial space into post-capillary venules, whereas particles between 10 and $100 \mathrm{~nm}$ and above $16 \mathrm{kDa}$ are efficiently removed from the interstitial space through the lymphatic system [56,109]. In addition, the drainage of fluids in the lymph capillaries is also significantly slower than drainage of fluids through the blood capillaries, which causes the majority of ARVs to pass directly into the blood and they are thus unaffected by the drug retention associated with the lymphatic system (Figure 2). Finally, co-dissolving multiple hydrophobic drugs like ARVs may result in inaccurate dosing due to aggregation or precipitation.

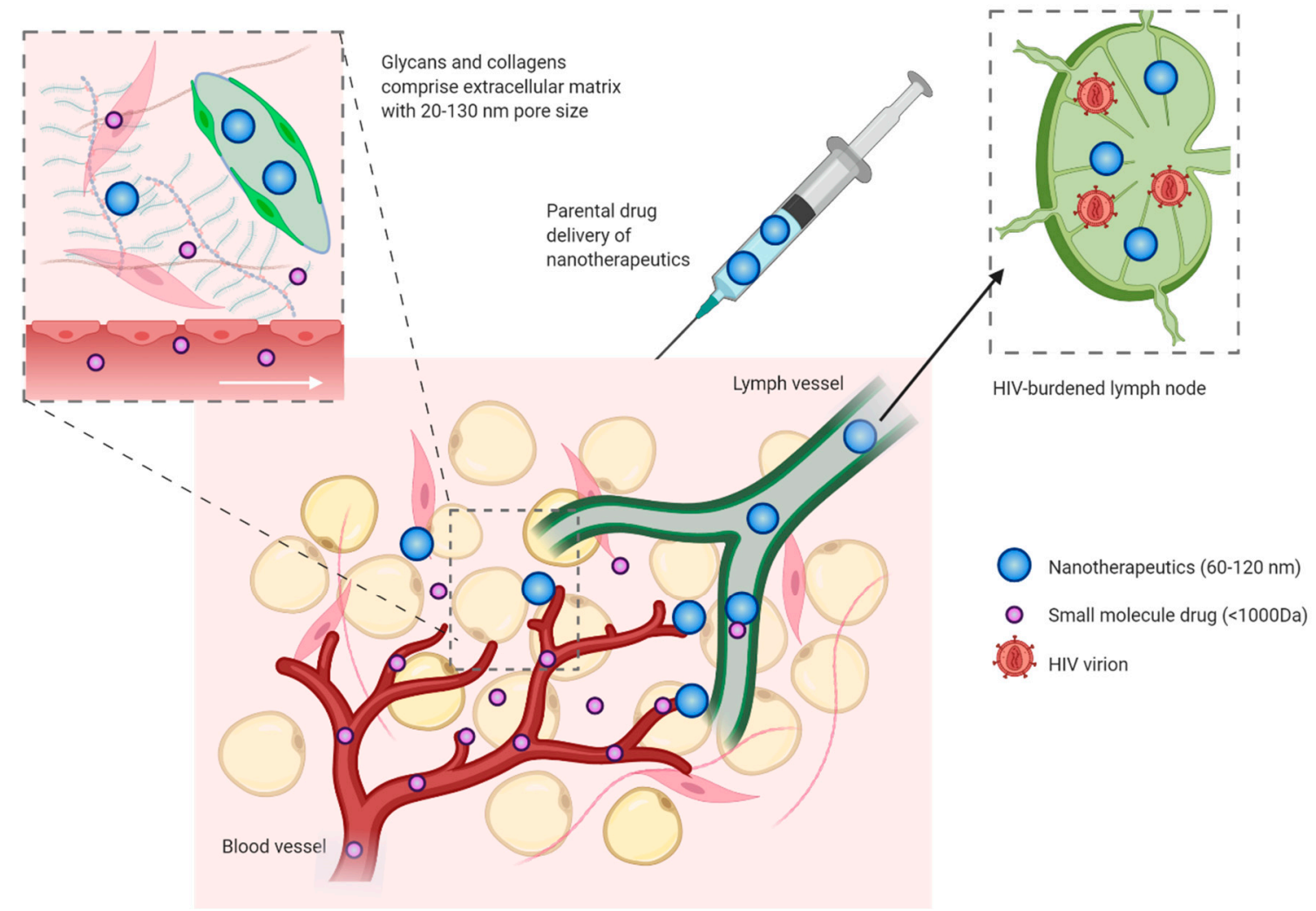

Figure 2. Interstitial space draining of nanotherapeutics. After subcutaneous injection of the nanotherapeutic particles, they will be dispersed in the interstitial space. This space is comprised of cells and an extracellular matrix, composed of glycans and collagens that will allow free passage of smaller molecules [63]. Based on size and physicochemical properties, such as lipophilicity, nanoparticles can either be removed via the draining venules or the peripheral lymphatic capillaries. Small molecule drugs are preferentially cleared via the draining blood vessels [56,109]. Created with Biorender.com.

Along those lines, much attention has been given to delivery of modified lymph-compatible, nanotherapeutic ARVs that bypass the gut via parental administration. Contrasting to the protein composition between interstitial space and lymph capillaries, the lipid composition differs between these compartments because fats are readily resorbed into lymph [56,57]. This is relevant for lipid-based nanotherapeutic ARV delivery, based on subcutaneous administration. For example, lymphatic tissue localization of lipid-indinavir (IDV) particles via a passive diffusion strategy were explored [110-114]. 
IDV-particles were tested for antiviral (SIV) effects in non-human primates (NHPs) [110,111]. The results showed that $100 \mathrm{~nm}$ nanoparticles had optimal passive targeting abilities towards the lymphatic system, including the lymph nodes. Overall, the nanoparticles comprising the lipid-indinavir (IDV) complex resulted in up to 23-fold higher concentration of IDV in peripheral and visceral LNs [110].

The mechanism causing the biodistribution of nanoparticles in the lymphatic system have been investigated [115]. Specifically, it was shown that nanoparticles administered subcutaneously were retained intra-lymphatically and subsequently distributed to the entire mouse body [114,115]. This effect was ascribed to the relatively large size of the molecules (60-120 nm) preventing extravasation from lymph vessels, which blocks release into the blood stream and enables transport from lymph node to lymph node through interconnected lymphatic vessels [115] (such effect shown in Figure 2). In addition, the same research group have shown anti-HIV efficacy of a lipid formulation of three ARVs that alone have different solubilities (lopinavir, ritonavir and tenofovir). This combination was dubbed "the targeted, long-acting and combination anti-retroviral therapy" (TLC-ART). The main findings were enhanced and showed persistent drug levels throughout the body of NHPs for over a week [114], and importantly not exclusively in the draining, sentinel lymph nodes [110,112,116]. However, more research is needed in order to fully understand how compounds are retained intra-lymphatically.

\section{Cellular Targeting}

Particularly intriguing for HIV cure therapy is the direct targeting of compounds to specific cell types to achieve an increased drug concentration at certain anatomical locations. Targeting only cells that harbor virus or have a higher likelihood of being HIV-infected could reduce the off-target effects of the drug [62].

In theory, using a molecule with an affinity for a specific cell surface epitope could aid in drugs only interacting with the desired target. The HIV receptor, CD4, and co-receptor CCR5 have both been investigated for the purpose of delivering ARV [117]. Yang et al. attempted to deliver antiretroviral therapy in HIV-susceptible SUP-T1 lymphoblasts via anti-CD4-antibody-coated nanoparticles containing saquinavir [118]. They observed a two-fold increase in intracellular saquinavir concentrations. A similar approach, but with anti-CD4 antibody-coated liposomes with nevirapine and saquinavir, has also been explored [119]. Another strategy has also been tested with the direct conjugation of bryostatin (a protein kinase C activator) to anti-CD4 antibodies for reversing HIV latency in resting CD4+ T cells. In this study, they found that it was possible to increase activation of CD4 cells when targeting the nanoparticles to the CD4 receptor [120]. Lastly, a different strategy used fragments of gp120 conjugated to nanoparticles for achieving drug delivery of indinavir to HIV-infected CD4+ cells to increase the efficacy of the drugs [121,122].

Common for these targeting studies is minimal improvements in efficacy over native drugs. Missing is the evidence of actual intracellular uptake, to disprove that drugs are released extracellularly after binding to target via linker degradation. In fact, the CD4 molecule does not readily internalize, and this could compromise CD4 targeting as a feasible strategy [123,124]. Conversely, HIV peptides present on infected cells could also be the target. However, upon HIV infection, resting cells display limited expression of gp120 and other HIV proteins, which results in reduced viral targets for drug delivery. Despite this fact, efforts were made by Pollock et al. to deliver NB-DNF (an inhibitor of HIV gp120 folding) via liposomes coated with CD4 molecules to gp120-expressing cells [125]. The study showed the efficient viral inhibition of different HIV laboratory strains with up to $10^{5}$-fold increase in potency compared to free NB-DNF. The cells in this study were acutely infected with HIV, thus not a clear reflection of the clinical setting with years of HIV infection and latency.

A third and perhaps ideal, sophisticated approach to cellular targeting is to find a cell-derived epitope, only expressed on HIV-infected cells. A great deal of work has searched for a surface marker that could define an HIV-infected cell. Among such markers, CD32a was suggested to be preferentially expressed on cells harboring replication-competent HIV [126,127]. However, this finding was questioned by other research groups [128-132]. Additionally, two reports have investigated CD30 
as a marker on CD4+ T cells which may be an interesting target $[133,134]$. These works highlight the importance, if possible, to define a reliable marker of HIV infection, but clearly continued research in basic cell biology and virology is needed in order to determine the feasibility of such approach.

\section{Nanotherapeutics in an HIV-Cure Context}

As briefly mentioned, the predominant strategy pursued in clinics (the shock and kill approach) may also benefit from modifications in drug delivery or formulation. LRAs such as histone deacetylase inhibitors (HDAC inhibitors) are widely used to reactivate latently infected cells [135]. During LRA treatment, cells are prevented from spreading HIV due to the presence of cART.

Nanotherapy could have a major role to play in this two-arm strategy. LRAs, like ARVs, are a group of mostly small molecule compounds $(<1000 \mathrm{Da})$, and but diverse physicochemical properties and biological targets, and could thus similarly benefit from novel formulations strategies. Our group and others have attempted to synthetize LRAs in nanoparticles [86,87]. Following polymer linking of panobinostat (an LRA), we observed HIV-latency reversal in two latently infected cell lines, ACH2 (T cells) and U1 (monocytes). Thus, it is possible to develop polymer molecules conjugated with LRAs through SILs to achieve intracellular effects. Further, polymers and lipid-structured nanoparticles have been used to deliver LRAs in combination with direct ARVs. Nelfinavir, a protease inhibitor and bryostatin-2, was formulated into a lipid nanoparticle in the study by Kovochich et al. [120]. This enabled the reactivation and control of viral spreading in human $\mathrm{T}$ cell lines and latently infected cells isolated from humanized mice. Another preclinical study has shown a nanoparticle combination of vorinostat and tenofovir that was effective in the reactivation and suppression of HIV replication for five days in human astrocytes [136]. Further, Tang et al. used anti-CD45RO single chain variable fragments ( $\mathrm{scFv}$ ) of antibodies (targeting memory T cells) to direct a PLGA-PEG nanoparticle with vorinostat and nelfinavir to target cells harboring virus, while preventing infection of new cells [137]. They found binding of the memory $\mathrm{T}$ cells and blockage of the production of new virions.

In summary, these pioneering studies elucidate the creativity as well as the broad flexibility found within nanotherapeutic design and synthesis, which can be used to both target, reverse latency and deliver CART.

\section{Future Directions}

A treatment able to completely clear or control HIV in patients could have huge commercial prospects. The use of nanotechnology within pharma has already influenced the development of novel therapeutic compounds, especially for cancer treatment. The overall conclusion is that within nanotechnology lies opportunities for the development of compounds that use known and safe ARVs in new formulations that could aid in overcoming some of the shortcomings of current HIV treatment. This includes aims to (1) increase drug solubility, (2) extend plasma half-life and bioavailability, (3) targeted to- and enhanced retention in HIV-burdened tissues and cells, (4) deliver precise ratios of combination therapy leading to synergistic effects. In addition, the adaptation of HIV cure drugs to biocompatible nanotherapeutic scaffolds could aid in improved biodistribution, pharmacokinetic profiles and tissue targeting, as well as decreasing dose-related toxicities. Moreover, modeling the ratios of different therapeutics with different biological targets on a scaffold could reveal novel synergistic combinations by ensuring that drugs were delivered in precise amounts to the target cell or organ. A sterilizing cure for HIV has become imaginable with the advancement of gene therapy. This includes complete removal of the provirus by e.g., CRISPR-Cas9-mediated excision. Utilizing a nanotherapeutic drug delivery approach to tissues could potential overcome problems with both delivery of guide RNAs as well as reduce off-target effects [138].

The application of nanotherapy for HIV treatment and cure still face important obstacles. Despite improvements in formulation chemistry, achieving sufficient production scaling for the treatment of millions of individuals without compromising batch-to-batch and intra-batch variations remains challenging for most nanotherapeutic designs. Moreover, given the fact that most HIV-infected 
individuals are based in low-income countries, keeping production costs at a minimum is highly relevant. Finally, addressing the safety in case of adverse events and enable rapid drug discontinuation is a key.

Author Contributions: A.H.F.A and M.T. both contributed to writing the manuscript. A.H.F.A. made the figures. All authors have read and agreed to the published version of the manuscript.

Funding: M.T. was funded by a grant from the Novo Nordisk Foundation (NNF19OC0054577). M.T. and A.H.F.A. was funded by a grant from the Independent Research Fund Denmark (9039-00039B).

Conflicts of Interest: The authors declare no conflict of interest.

\section{References}

1. UNAIDS. Global HIV Statistics-Fact Sheet; UNAIDS 2019. Available online: https://www.unaids.org/sites/ default/files/media_asset/UNAIDS_FactSheet_en.pdf (accessed on 13 January 2020).

2. Blankson, J.N.; Persaud, D.; Siliciano, R.F. The Challenge of Viral Reservoirs in HIV-1 Infection. Annu. Rev. Med. 2002, 53, 557-593. [CrossRef] [PubMed]

3. Estes, J.D.; Kityo, C.; Ssali, F.; Swainson, L.; Makamdop, K.N.; Del Prete, G.Q.; Deeks, S.G.; Luciw, P.A.; Chipman, J.G.; Beilman, G.J.; et al. Defining total-body AIDS-virus burden with implications for curative strategies. Nat. Med. 2017, 23, 1271-1276. [CrossRef] [PubMed]

4. Fletcher, C.V.; Staskus, K.; Wietgrefe, S.W.; Rothenberger, M.; Reilly, C.; Chipman, J.G.; Beilman, G.J.; Khoruts, A.; Thorkelson, A.; Schmidt, T.E.; et al. Persistent HIV-1 replication is associated with lower antiretroviral drug concentrations in lymphatic tissues. Proc. Natl. Acad. Sci. USA 2014, 111, 2307-2312. [CrossRef] [PubMed]

5. Henrich, T.J; Hatano, H.; Bacon, O.; Hogan, L.E.; Rutishauser, R.; Hill, A.; Kearney, M.F.; Anderson, E.M.; Buchbinder, S.P.; Cohen, S.E.; et al. HIV-1 persistence following extremely early initiation of antiretroviral therapy (ART) during acute HIV-1 infection: An observational study. PLoS Med. 2017, 14, e1002417. [CrossRef] [PubMed]

6. Lorenzo-Redondo, R.; Fryer, H.R.; Bedford, T.; Kim, E.Y.; Archer, J.; Kosakovsky Pond, S.L.; Chung, Y.S.; Penugonda, S.; Chipman, J.G.; Fletcher, C.V.; et al. Persistent HIV-1 replication maintains the tissue reservoir during therapy. Nature 2016, 530, 51-56. [CrossRef]

7. Deeks, S.G. Shock and kill. Nature 2012, 487, 439-440. [CrossRef]

8. Berg, S.L.; Stone, J.; Xiao, J.J.; Chan, K.K.; Nuchtern, J.; Dauser, R.; McGuffey, L.; Thompson, P.; Blaney, S.M. Plasma and cerebrospinal fluid pharmacokinetics of depsipeptide (FR901228) in nonhuman primates. Cancer Chemother. Pharmacol. 2004, 54, 85-88. [CrossRef]

9. Gupta, S.; Kesarla, R.; Omri, A. Approaches for CNS delivery of drugs-nose to brain targeting of antiretroviral agents as a potential attempt for complete elimination of major reservoir site of HIV to aid AIDS treatment. Expert Opin. Drug Deliv. 2019, 16, 287-300. [CrossRef]

10. Varghese, N.M.; Senthil, V.; Saxena, S.K. Nanocarriers for brain specific delivery of anti-retro viral drugs: Challenges and achievements. J. Drug Target. 2018, 26, 195-207. [CrossRef]

11. Davey, R.T.; Bhat, N.; Yoder, C.; Chun, T.W.; Metcalf, J.A.; Dewar, R.; Natarajan, V.; Lempicki, R.A.; Adelsberger, J.W.; Miller, K.D.; et al. HIV-1 and T cell dynamics after interruption of highly active antiretroviral therapy (HAART) in patients with a history of sustained viral suppression. Proc. Natl. Acad. Sci. USA 1999, 96, 15109-15114. [CrossRef]

12. Arts, E.J.; Hazuda, D.J. HIV-1 antiretroviral drug therapy. Cold Spring Harb. Perspect. Med. 2012, 2, a007161. [CrossRef] [PubMed]

13. Stagg, M.P.; Cretton, E.M.; Kidd, L.; Diasio, R.B.; Sommadossi, J.-P. Clinical pharmacokinetics of $3^{\prime}$-azido-3'-deoxythymidine (zidovudine) and catabolites with formation of a toxic catabolite, 3'-amino-3'-deoxythymidine. Clin. Pharmacol. Ther. 1992, 51, 668-676. [CrossRef] [PubMed]

14. Balimane, P.V.; Sinko, P.J. Involvement of multiple transporters in the oral absorption of nucleoside analogues. Adv. Drug Deliv. Rev. 1999, 39, 183-209. [CrossRef]

15. Grasela, D.M.; Stoltz, R.R.; Barry, M.; Bone, M.; Mangold, B.; O'Grady, P.; Raymond, R.; Haworth, S.J. Pharmacokinetics of single-dose oral stavudine in subjects with renal impairment and in subjects requiring hemodialysis. Antimicrob. Agents Chemother. 2000, 44, 2149-2153. [CrossRef] 
16. Johnson, M.A.; Moore, K.H.; Yuen, G.J.; Bye, A.; Pakes, G.E. Clinical pharmacokinetics of lamivudine. Clin. Pharmacokinet. 1999, 36, 41-66. [CrossRef]

17. Johnson, M.A.; Horak, J.; Breuel, P. The pharmacokinetics of lamivudine in patients with impaired hepatic function. Eur. J. Clin. Pharmacol. 1998, 54, 363-366. [CrossRef]

18. McDowell, J.A.; Lou, Y.; Symonds, W.S.; Stein, D.S. Multiple-dose pharmacokinetics and pharmacodynamics of abacavir alone and in combination with zidovudine in human immunodeficiency virus-infected adults. Antimicrob. Agents Chemother. 2000, 44, 2061-2067. [CrossRef]

19. Kearney, B.P.; Yale, K.; Shah, J.; Zhong, L.; Flaherty, J.F. Pharmacokinetics and dosing recommendations of tenofovir disoproxil fumarate in hepatic or renal impairment. Clin. Pharmacokinet. 2006, 45, 1115-1124. [CrossRef]

20. Custodio, J.M.; Fordyce, M.; Garner, W.; Vimal, M.; Ling, K.H.J.; Kearney, B.P.; Ramanathan, S. Pharmacokinetics and safety of tenofovir alafenamide in HIV-uninfected subjects with severe renal impairment. Antimicrob. Agents Chemother. 2016, 60, 5135-5140. [CrossRef]

21. Lamorde, M.; Byakika-Kibwika, P.; Tamale, W.S.; Kiweewa, F.; Ryan, M.; Amara, A.; Tjia, J.; Back, D.; Khoo, S.; Boffito, M.; et al. Effect of food on the steady-state pharmacokinetics of tenofovir and emtricitabine plus efavirenz in ugandan adults. AIDS Res. Treat. 2012, 2012, 1-6. [CrossRef]

22. To, K.W.; Liu, S.T.; Cheung, S.W.; Chan, D.P.C.; Chan, R.C.Y.; Lee, S.S. Pharmacokinetics of plasma efavirenz and CYP2B6 polymorphism in Southern Chinese. Ther. Drug Monit. 2009, 31, 527-530. [CrossRef] [PubMed]

23. Van Heeswijk, R.P.G.; Veldkamp, A.I.; Mulder, J.W.; Meenhorst, P.L.; Wit, F.W.N.M.; Lange, J.M.A.; Danner, S.A.; Foudraine, N.A.; Kwakkelstein, M.O.; Reiss, P.; et al. The steady-state pharmacokinetics of nevirapine during once daily and twice daily dosing in HIV-1-infected individuals. AIDS 2000, 14, F77-F82. [CrossRef] [PubMed]

24. De Maat, M.M.R.; Huitema, A.D.R.; Mulder, J.W.; Meenhorst, P.L.; Van Gorp, E.C.M.; Beijnen, J.H. Population pharmacokinetics of nevirapine in an unselected cohort of HIV-1-infected individuals. Br. J. Clin. Pharmacol. 2002, 54, 378-385. [CrossRef] [PubMed]

25. Clarke, S.M.; Mulcahy, F.M.; Tjia, J.; Reynolds, H.E.; Gibbons, S.E.; Barry, M.G.; Back, D.J. Pharmacokinetic Interactions of Nevirapine and Methadone and Guidelines for Use of Nevirapine to Treat Injection Drug Users. Clin. Infect. Dis. 2001, 33, 1595-1597. [CrossRef] [PubMed]

26. Battegay, M.; Arasteh, K.; Plettenberg, A.; Bogner, J.R.; Livrozet, J.M.; Witt, M.D.; Mossdorf, E.; Yong, C.L.; Zhang, W.; Macha, S.; et al. Bioavailability of Extended-Release Nevirapine 400 and $300 \mathrm{mg}$ in HIV-1: A Multicenter, Open-Label Study. Clin. Ther. 2011, 33, 1308-1320. [CrossRef] [PubMed]

27. Yong, C.L.; Gathe, J.C.; Knecht, G.; Orrell, C.; Mallolas, J.; Podzamczer, D.; Trottier, B.; Zhang, W.; Sabo, J.P.; Vinisko, R.; et al. Pharmacokinetic analysis of nevirapine extended release $400 \mathrm{mg}$ once daily vs nevirapine immediate release $200 \mathrm{mg}$ twice daily formulation in treatment-naïve patients with HIV-1 infection. HIV Clin. Trials 2017, 18, 189-195. [CrossRef]

28. Schöller-Gyüre, M.; Kakuda, T.N.; De Smedt, G.; Woodfall, B.; Berckmans, C.; Peeters, M.; Hoetelmans, R.M.W. Effects of hepatic impairment on the steady-state pharmacokinetics of etravirine $200 \mathrm{mg}$ BID: An open-label, multiple-dose, controlled Phase I study in adults. Clin. Ther. 2010, 32, 328-337. [CrossRef]

29. John, J.; Liang, D. Oral liquid formulation of etravirine for enhanced bioavailability. J. Bioequivalence Bioavailab. 2014, 6, 46-52.

30. Crauwels, H.M.; Van Heeswijk, R.P.G.; Buelens, A.; Stevens, M.; Boven, K.; Hoetelmans, R.M.W. Impact of food and different meal types on the pharmacokinetics of rilpivirine. J. Clin. Pharmacol. 2013, 53, 834-840. [CrossRef]

31. Washington, C.B.; Flexner, C.; Sheiner, L.B.; Rosenkranz, S.L.; Segal, Y.; Aberg, J.A.; Blaschke, T.F. Effect of simultaneous versus staggered dosing on pharmacokinetic interactions of protease inhibitors. Clin. Pharmacol. Ther. 2003, 73, 406-416. [CrossRef]

32. Hsu, A.; Isaacson, J.; Brun, S.; Bernstein, B.; Lam, W.; Bertz, R.; Foit, C.; Rynkiewicz, K.; Richards, B.; King, M.; et al. Pharmacokinetic-pharmacodynamic analysis of lopinavir-ritonavir in combination with efavirenz and two nucleoside reverse transcriptase inhibitors in extensively pretreated human immunodeficiency virus-infected patients. Antimicrob. Agents Chemother. 2003, 47, 350-359. [CrossRef] [PubMed]

33. Yeh, K.C.; Deutsch, P.J.; Haddix, H.; Hesney, M.; Hoagland, V.; Ju, W.D.; Justice, S.J.; Osborne, B.; Sterrett, A.T.; Stone, J.A.; et al. Single-dose pharmacokinetics of indinavir and the effect of food. Antimicrob Agents Chemother 1998, 42, 332-338. [CrossRef] [PubMed] 
34. Damle, B.; Hewlett, D.; Hsyu, P.H.; Becker, M.; Petersen, A. Pharmacokinetics of nelfinavir in subjects with hepatic impairment. J. Clin. Pharmacol. 2006, 46, 1241-1249. [CrossRef] [PubMed]

35. Musiime, V.; Fillekes, Q.; Kekitiinwa, A.; Kendall, L.; Keishanyu, R.; Namuddu, R.; Young, N.; Opilo, W.; Lallemant, M.; Walker, A.S.; et al. The pharmacokinetics and acceptability of lopinavir/ritonavir minitab sprinkles, tablets, and syrups in african HIV-infected children. J. Acquir. Immune Defic. Syndr. 2014, 66, 148-154. [CrossRef]

36. Veronese, L.; Rautaureau, J.; Sadler, B.M.; Gillotin, C.; Petite, J.P.; Pillegand, B.; Delvaux, M.; Masliah, C.; Fosse, S.; Lou, Y.; et al. Single-dose pharmacokinetics of amprenavir, a human immunodeficiency virus type 1 protease inhibitor, in subjects with normal or impaired hepatic function. Antimicrob. Agents Chemother. 2000, 44, 821-826. [CrossRef]

37. Sevinsky, H.; Tao, X.; Wang, R.; Ravindran, P.; Sims, K.; Xu, X.; Jariwala, N.; Bertz, R. A randomized trial in healthy subjects to assess the bioequivalence of an atazanavir/cobicistat fixed-dose combination tablet versus administration as separate agents. Antivir. Ther. 2015, 20, 493-500. [CrossRef]

38. MacGregor, T.R.; Sabo, J.P.; Norris, S.H.; Johnson, P.; Galitz, L.; McCallister, S. Pharmacokinetic characterization of different dose combinations of coadministered tipranavir and ritonavir in healthy volunteers. HIV Clin. Trials 2004, 5, 371-382. [CrossRef]

39. Sekar, V.; Kestens, D.; Spinosa-Guzman, S.; De Pauw, M.; De Paepe, E.; Vangeneugden, T.; Lefebvre, E.; Hoetelmans, R.M.W. The effect of different meal types on the pharmacokinetics of darunavir (TMC114)/ritonavir in HIV-negative healthy volunteers. J. Clin. Pharmacol. 2007, 47, 479-484. [CrossRef]

40. Rittweger, M.; Arastéh, K. Clinical pharmacokinetics of darunavir. Clin. Pharmacokinet. 2007, 46, 739-756. [CrossRef]

41. Kilby, J.M.; Lalezari, J.P.; Eron, J.J.; Carlson, M.; Cohen, C.; Arduino, R.C.; Goodgame, J.C.; Gallant, J.E.; Volberding, P.; Murphy, R.L.; et al. The safety, plasma pharmacokinetics, and antiviral activity of subcutaneous enfuvirtide (T-20), a peptide inhibitor of gp41-mediated virus fusion, in HIV-infected adults. AIDS Res. Hum. Retrovir. 2002, 18, 685-693. [CrossRef]

42. Abel, S.; Russell, D.; Whitlock, L.A.; Ridgway, C.E.; Nedderman, A.N.R.; Walker, D.K. Assessment of the absorption, metabolism and absolute bioavailability of maraviroc in healthy male subjects. Br. J. Clin. Pharmacol. 2008, 65, 60-67. [CrossRef] [PubMed]

43. Song, I.; Borland, J.; Chen, S.; Patel, P.; Wajima, T.; Peppercorn, A.; Piscitelli, S.C. Effect of food on the pharmacokinetics of the integrase inhibitor dolutegravir. Antimicrob. Agents Chemother. 2012, 56, 1627-1629. [CrossRef] [PubMed]

44. Moss, L.; Wagner, D.; Kanaoka, E.; Olson, K.; Yueh, Y.L.; Bowers, G.D. The comparative disposition and metabolism of dolutegravir, a potent HIV-1 integrase inhibitor, in mice, rats, and monkeys. Xenobiotica 2015, 45, 60-70. [CrossRef] [PubMed]

45. Mathias, A.A.; West, S.; Hui, J.; Kearney, B.P. Dose-response of ritonavir on hepatic CYP3A activity and elvitegravir oral exposure. Clin. Pharmacol. Ther. 2009, 85, 64-70. [CrossRef] [PubMed]

46. Assessment Report of Vitekta, EMA/701401/2013, European Medicines Agency. Available online: https: //www.ema.europa.eu/en/medicines/human/EPAR/vitekta (accessed on 5 September 2019).

47. Iwamoto, M.; Hanley, W.D.; Petry, A.S.; Friedman, E.J.; Kost, J.T.; Breidinger, S.A.; Lasseter, K.C.; Robson, R.; Lunde, N.M.; Wenning, L.A.; et al. Lack of a clinically important effect of moderate hepatic insufficiency and severe renal insufficiency on raltegravir pharmacokinetics. Antimicrob. Agents Chemother. 2009, 53, 1747-1752. [CrossRef] [PubMed]

48. Gallant, J.E.; Thompson, M.; DeJesus, E.; Voskuhl, G.W.; Wei, X.; Zhang, H.; White, K.; Cheng, A.; Quirk, E.; Martin, H. Antiviral activity, safety, and pharmacokinetics of bictegravir as 10-day monotherapy in HIV-1-infected adults. J. Acquir. Immune Defic. Syndr. 2017, 75, 61-66. [CrossRef]

49. Gao, Y.; Kraft, J.C.; Yu, D.; Ho, R.J.Y. Recent developments of nanotherapeutics for targeted and long-acting, combination HIV chemotherapy. Eur. J. Pharm. Biopharm. 2019, 138, 75-91. [CrossRef]

50. Devi, K.; Pai, R. Antiretrovirals: Need for an effective drug delivery. Indian J. Pharm. Sci. 2006, 68, 1-6. [CrossRef]

51. Wuyts, B.; Brouwers, J.; Mols, R.; Tack, J.; Annaert, P.; Augustijns, P. Solubility profiling of HIV protease inhibitors in human intestinal fluids. J. Pharm. Sci. 2013, 102, 3800-3807. [CrossRef]

52. Bastiaans, D.E.; Cressey, T.R.; Vromans, H.; Burger, D.M. The role of formulation on the pharmacokinetics of antiretroviral drugs. Expert Opin. Drug Metab. Toxicol. 2014, 10, 1019-1037. [CrossRef] 
53. Amin, M.L. P-glycoprotein inhibition for optimal drug delivery. Drug Target. Insights 2013, 2013, $27-34$. [CrossRef]

54. Wilkinson, G.R. Cytochrome P4503A (CYP3A) metabolism: Prediction of in vivo activity in humans. J. Pharmacokinet. Biopharm. 1996, 24, 475-490. [CrossRef] [PubMed]

55. Buchanan, C.M.; Buchanan, N.L.; Edgar, K.J.; Little, J.L.; Ramsey, M.G.; Ruble, K.M.; Wacher, V.J.; Wempe, M.F. Pharmacokinetics of saquinavir after intravenous and oral dosing of Saquinavir: Hydroxybutenyl- $\beta$-cyclodextrin formulations. Biomacromolecules 2008, 9, 305-313. [CrossRef]

56. Swartz, M.A. The physiology of the lymphatic system. Adv. Drug Deliv. Rev. 2001, 50, 3-20. [CrossRef]

57. Trevaskis, N.L.; Charman, W.N.; Porter, C.J.H. Lipid-based delivery systems and intestinal lymphatic drug transport: A mechanistic update. Adv. Drug Deliv. Rev. 2008, 60, 702-716. [CrossRef] [PubMed]

58. Yáñez, J.A.; Wang, S.W.J.; Knemeyer, I.W.; Wirth, M.A.; Alton, K.B. Intestinal lymphatic transport for drug delivery. Adv. Drug Deliv. Rev. 2011, 63, 923-942. [CrossRef] [PubMed]

59. Trezza, C.R.; Kashuba, A.D.M. Pharmacokinetics of antiretrovirals in genital secretions and anatomic sites of HIV transmission: Implications for HIV prevention. Clin. Pharmacokinet. 2014, 53, 611-624. [CrossRef]

60. Palmer, S.; Maldarelli, F.; Wiegand, A.; Bernstein, B.; Hanna, G.J.; Brun, S.C.; Kempf, D.J.; Mellors, J.W.; Coffin, J.M.; King, M.S. Low-level viremia persists for at least 7 years in patients on suppressive antiretroviral therapy. Proc. Natl. Acad. Sci. USA 2008, 105, 3879-3884. [CrossRef]

61. Kearney, M.F.; Wiegand, A.; Shao, W.; Coffin, J.M.; Mellors, J.W.; Lederman, M.; Gandhi, R.T.; Keele, B.F.; Li, J.Z. Origin of Rebound Plasma HIV Includes Cells with Identical Proviruses That Are Transcriptionally Active before Stopping of Antiretroviral Therapy. J. Virol. 2016, 90, 1369-1376. [CrossRef]

62. Gunaseelan, S.; Gunaseelan, K.; Deshmukh, M.; Zhang, X.; Sinko, P.J. Surface modifications of nanocarriers for effective intracellular delivery of anti-HIV drugs. Adv. Drug Deliv. Rev. 2010, 62, 518-531. [CrossRef]

63. Shao, J.; Kraft, J.C.; Li, B.; Yu, J.; Freeling, J.; Koehn, J.; Ho, R.J. Nanodrug formulations to enhance HIV drug exposure in lymphoid tissues and cells: Clinical significance and potential impact on treatment and eradication of HIV/AIDS. Futur. Med. 2016, 11, 545-564. [CrossRef] [PubMed]

64. Barenholz, Y. Doxil ${ }^{\circledR}$-The first FDA-approved nano-drug: Lessons learned. J. Control. Release 2012, 160, 117-134. [CrossRef] [PubMed]

65. Tejada-Berges, T.; Granai, C.O.; Gordinier, M.; Gajewski, W. Caelyx/Doxil for the treatment of metastatic ovarian and breast cancer. Expert Rev. Anticancer Ther. 2002, 2, 143-150. [CrossRef] [PubMed]

66. O’Brien, M.E.R.; Wigler, N.; Inbar, M.; Rosso, R.; Grischke, E.; Santoro, A.; Catane, R.; Kieback, D.G.; Tomczak, P.; Ackland, S.P.; et al. Reduced cardiotoxicity and comparable efficacy in a phase III trial of pegylated liposomal doxorubicin $\mathrm{HCl}\left(\mathrm{CAELY} \mathrm{X}^{\mathrm{TM}} /\right.$ Doxil $\left.^{\circledR}\right)$ versus conventional doxorubicin for first-line treatment of metastatic breast cancer. Ann. Oncol. 2004, 15, 440-449. [CrossRef] [PubMed]

67. Frenkel, V.; Etherington, A.; Greene, M.; Quijano, J.; Xie, J.; Hunter, F.; Dromi, S.; Li, K.C.P. Delivery of liposomal doxorubicin (Doxil) in a breast cancer tumor model: Investigation of potential enhancement by pulsed-high intensity focused ultrasound exposure. Acad. Radiol. 2006, 13, 469-479. [CrossRef] [PubMed]

68. Garrido, C.; Simpson, C.A.; Dahl, N.P.; Bresee, J.; Whitehead, D.C.; Lindsey, E.A.; Harris, T.L.; Smith, C.A.; Carter, C.J.; Feldheim, D.L.; et al. Gold nanoparticles to improve HIV drug delivery. Future Med. Chem. 2015, 7, 1097-1107. [CrossRef]

69. Cao, S.; Woodrow, K.A. Nanotechnology approaches to eradicating HIV reservoirs. Eur. J. Pharm. Biopharm. 2019, 138, 48-63. [CrossRef]

70. Lara, H.H.; Ixtepan-Turrent, L.; Garza Treviño, E.N.; Singh, D.K. Use of silver nanoparticles increased inhibition of cell-associated HIV-1 infection by neutralizing antibodies developed against HIV-1 envelope proteins. J. Nanobiotechnology 2011, 9, 38. [CrossRef]

71. Chopra, S.; Venkatesan, N.; Betageri, G.V. Liposomes as nanocarriers for anti-HIV therapy. Drug Deliv. Transl. Res. 2013, 3, 471-478. [CrossRef]

72. Kraft, J.C.; Freeling, J.P.; Wang, Z.; Ho, R.J.Y. Emerging research and clinical development trends of liposome and lipid nanoparticle drug delivery systems. J. Pharm. Sci. 2014, 103, 29-52. [CrossRef]

73. Duncan, R. The dawning era of polymer therapeutics. Nat. Rev. Drug Discov. 2003, 2, 347-360. [CrossRef] [PubMed]

74. Aggarwal, P.; Hall, J.B.; McLeland, C.B.; Dobrovolskaia, M.A.; McNeil, S.E. Nanoparticle interaction with plasma proteins as it relates to particle biodistribution, biocompatibility and therapeutic efficacy. Adv. Drug Deliv. Rev. 2009, 61, 428-437. [CrossRef] [PubMed] 
75. Müller, R.H.; Gohla, S.; Keck, C.M. State of the art of nanocrystals-Special features, production, nanotoxicology aspects and intracellular delivery. Eur. J. Pharm. Biopharm. 2011, 78, 1-9. [CrossRef] [PubMed]

76. Owen, A.; Rannard, S. Strengths, weaknesses, opportunities and challenges for long acting injectable therapies: Insights for applications in HIV therapy. Adv. Drug Deliv. Rev. 2016, 103, 144-156. [CrossRef]

77. Margolis, D.A.; Gonzalez-Garcia, J.; Stellbrink, H.J.; Eron, J.J.; Yazdanpanah, Y.; Podzamczer, D.; Lutz, T.; Angel, J.B.; Richmond, G.J.; Clotet, B.; et al. Long-acting intramuscular cabotegravir and rilpivirine in adults with HIV-1 infection (LATTE-2): 96-week results of a randomised, open-label, phase 2b, non-inferiority trial. Lancet 2017, 390, 1499-1510. [CrossRef]

78. Whitfield, T.; Torkington, A.; van Halsema, C. Profile of cabotegravir and its potential in the treatment and prevention of HIV-1 infection: Evidence to date. HIV/AIDS Res. Palliat. Care 2016, 8, 157-164. [CrossRef]

79. ViiV Healthcare submits New Drug Application to US FDA ViiV Healthcare. Available online: https://www.viivhealthcare.com/en-gb/media/press-releases/2019/april/viiv-healthcare-submits-newdrug-application-to-us-fda-for-the-first-monthly-injectable-two-drug-regimen-of-cabotegravir-andrilpivirine-for-treatment-of-hiv/ (accessed on 22 August 2019).

80. Yant, S.R.; Mulato, A.; Hansen, D.; Tse, W.C.; Niedziela-Majka, A.; Zhang, J.R.; Stepan, G.J.; Jin, D.; Wong, M.H.; Perreira, J.M.; et al. A highly potent long-acting small-molecule HIV-1 capsid inhibitor with efficacy in a humanized mouse model. Nat. Med. 2019, 25, 1377-1384. [CrossRef]

81. Riber, C.F.; Smith, A.A.A.; Zelikin, A.N. Self-Immolative Linkers Literally Bridge Disulfide Chemistry and the Realm of Thiol-Free Drugs. Adv. Healthc. Mater. 2015, 4, 1-4. [CrossRef]

82. Andersen, A.H.F.; Riber, C.F.; Zuwala, K.; Tolstrup, M.; Dagnæs-Hansen, F.; Denton, P.W.; Zelikin, A.N. Long-Acting, Potent Delivery of Combination Antiretroviral Therapy. ACS Macro Lett. 2018, 7, 587-591. [CrossRef]

83. Danial, M.; Andersen, A.H.F.; Żuwała, K.; Cosson, S.; Riber, C.F.; Smith, A.A.A.; Tolstrup, M.; Moad, G.; Zelikin, A.N.; Postma, A. Triple Activity of Lamivudine Releasing Sulfonated Polymers against HIV-1. Mol. Pharm. 2016, 13, 2397-2410. [CrossRef]

84. Hinton, T.M.; Zuwala, K.; Deffrasnes, C.; Todd, S.; Shi, S.; Marsh, G.A.; Dearnley, M.; Wohl, B.M.; Tolstrup, M.; Zelikin, A.N. Polyanionic Macromolecular Prodrugs of Ribavirin: Antiviral Agents with a Broad Spectrum of Activity. Adv. Healthc. Mater. 2016, 5, 534-540. [CrossRef]

85. Kock, A.; Zuwala, K.; Smith, A.A.A.; Ruiz-Sanchis, P.; Wohl, B.M.; Tolstrup, M.; Zelikin, A.N. Disulfide reshuffling triggers the release of a thiol-free anti-HIV agent to make up fast-acting, potent macromolecular prodrugs. Chem. Commun. 2014, 50, 14498-14500. [CrossRef] [PubMed]

86. Zuwala, K.; Smith, A.A.A.; Tolstrup, M.; Zelikin, A.N. HIV anti-latency treatment mediated by macromolecular prodrugs of histone deacetylase inhibitor, panobinostat. Chem. Sci. 2016, 7, 2353-2358. [CrossRef] [PubMed]

87. Smith, A.A.A.; Zuwala, K.; Pilgram, O.; Johansen, K.S.; Tolstrup, M.; Dagnæs-Hansen, F.; Zelikin, A.N. Albumin-Polymer-Drug Conjugates: Long Circulating, High Payload Drug Delivery Vehicles. ACS Macro Lett. 2016, 5, 1089-1094. [CrossRef]

88. O'Hagan, D.; Singh, M.; Ugozzoli, M.; Wild, C.; Barnett, S.; Chen, M.; Schaefer, M.; Doe, B.; Otten, G.R.; Ulmer, J.B. Induction of Potent Immune Responses by Cationic Microparticles with Adsorbed Human Immunodeficiency Virus DNA Vaccines. J. Virol. 2001, 75, 9037-9043. [CrossRef]

89. Neeraj, A.; Chandrasekar, M.J.N.; Sara, U.V.S.; Rohini, A. Poly (HEMA-Zidovudine) conjugate: A macromolecular pro-drug for improvement in the biopharmaceutical properties of the drug. Drug Deliv. 2011, 18, 272-280. [CrossRef]

90. Schandock, F.; Riber, C.F.; Röcker, A.; Müller, J.A.; Harms, M.; Gajda, P.; Zuwala, K.; Andersen, A.H.F.; Løvschall, K.B.; Tolstrup, M.; et al. Macromolecular Antiviral Agents against Zika, Ebola, SARS, and Other Pathogenic Viruses. Adv. Healthc. Mater. 2017, 6, 1700748. [CrossRef]

91. Li, W.; Wang, Q.; Li, Y.; Yu, F.; Liu, Q.; Qin, B.; Xie, L.; Lu, L.; Jiang, S. A Nanoparticle-Encapsulated Non-Nucleoside Reverse-Transcriptase Inhibitor with Enhanced Anti-HIV-1 Activity and Prolonged Circulation Time in Plasma. Curr. Pharm. Des. 2014, 21, 925-935. [CrossRef]

92. Frich, C.K.; Krüger, F.; Walther, R.; Domar, C.; Andersen, A.H.F.; Tvilum, A.; Dagnæs-Hansen, F.; Denton, P.W.; Tolstrup, M.; Paludan, S.R.; et al. Non-covalent hitchhiking on endogenous carriers as a protraction mechanism for antiviral macromolecular prodrugs. J. Control. Release 2019, 294, 298-310. [CrossRef] 
93. Chaudhury, C.; Mehnaz, S.; Robinson, J.M.; Hayton, W.L.; Pearl, D.K.; Roopenian, D.C.; Anderson, C.L. The major histocompatibility complex-related $F_{c}$ receptor for $\operatorname{IgG}(\mathrm{FcRn})$ binds albumin and prolongs its lifespan. J. Exp. Med. 2003, 197, 315-322. [CrossRef]

94. Lau, J.; Bloch, P.; Schäffer, L.; Pettersson, I.; Spetzler, J.; Kofoed, J.; Madsen, K.; Knudsen, L.B.; McGuire, J.; Steensgaard, D.B.; et al. Discovery of the Once-Weekly Glucagon-Like Peptide-1 (GLP-1) Analogue Semaglutide. J. Med. Chem. 2015, 58, 7370-7380. [CrossRef] [PubMed]

95. Liu, H.; Moynihan, K.D.; Zheng, Y.; Szeto, G.L.; Li, A.V.; Huang, B.; Van Egeren, D.S.; Park, C.; Irvine, D.J. Structure-based programming of lymph-node targeting in molecular vaccines. Nature 2014, 507, 519-522. [CrossRef] [PubMed]

96. Li, W.; Yu, F.; Wang, Q.; Qi, Q.; Su, S.; Xie, L.; Lu, L.; Jiang, S. Co-delivery of HIV-1 entry inhibitor and nonnucleoside reverse transcriptase inhibitor shuttled by nanoparticles: Cocktail therapeutic strategy for antiviral therapy. AIDS 2016, 30, 827-837. [CrossRef]

97. Mandal, S.; Belshan, M.; Holec, A.; Zhou, Y.; Destache, C.J. An Enhanced Emtricitabine-Loaded Long-Acting Nanoformulation for Prevention or Treatment of HIV Infection. Antimicrob. Agents Chemother. 2017, 61, e01475-e01516. [CrossRef] [PubMed]

98. Mandal, S.; Kang, G.; Prathipati, P.K.; Zhou, Y.; Fan, W.; Li, Q.; Destache, C.J. Nanoencapsulation introduces long-acting phenomenon to tenofovir alafenamide and emtricitabine drug combination: A comparative pre-exposure prophylaxis efficacy study against HIV-1 vaginal transmission. J. Control. Release 2019, 294, 216-225. [CrossRef] [PubMed]

99. Mandal, S.; Prathipati, P.K.; Kang, G.; Zhou, Y.; Yuan, Z.; Fan, W.; Li, Q.; Destache, C.J. Tenofovir alafenamide and elvitegravir loaded nanoparticles for long-acting prevention of HIV-1 vaginal transmission. AIDS 2017, 31, 469-476. [CrossRef]

100. Destache, C.J.; Belgum, T.; Goede, M.; Shibata, A.; Belshan, M.A. Antiretroviral release from poly(DL-lactide-co-glycolide) nanoparticles in mice. J. Antimicrob. Chemother. 2010, 65, 2183-2187. [CrossRef]

101. Guo, D.; Zhang, G.; Wysocki, T.A.; Wysocki, B.J.; Gelbard, H.A.; Liu, X.-M.; McMillan, J.M.; Gendelman, H.E. Endosomal Trafficking of Nanoformulated Antiretroviral Therapy Facilitates Drug Particle Carriage and HIV Clearance. J. Virol. 2014, 88, 9504-9513. [CrossRef]

102. Williams, J.; Sayles, H.R.; Meza, J.L.; Sayre, P.; Sandkovsky, U.; Gendelman, H.E.; Flexner, C.; Swindells, S. Long-acting parenteral nanoformulated antiretroviral therapy: Interest and attitudes of HIV-infected patients. Nanomedicine 2013, 8, 1807-1813. [CrossRef]

103. Edagwa, B.; McMillan, J.E.; Sillman, B.; Gendelman, H.E. Long-acting slow effective release antiretroviral therapy. Expert Opin. Drug Deliv. 2017, 14, 1281-1291. [CrossRef]

104. Sillman, B.; Bade, A.N.; Dash, P.K.; Bhargavan, B.; Kocher, T.; Mathews, S.; Su, H.; Kanmogne, G.D.; Poluektova, L.Y.; Gorantla, S.; et al. Creation of a long-acting nanoformulated dolutegravir. Nat. Commun. 2018, 9, 443. [CrossRef] [PubMed]

105. Edagwa, B.; Zhou, T.; McMillan, J.; Liu, X.-M.; Gendelman, H. Development of HIV Reservoir Targeted Long Acting Nanoformulated Antiretroviral Therapies. Curr. Med. Chem. 2014, 21, 4186-4198. [CrossRef] [PubMed]

106. Dash, P.K.; Kaminski, R.; Bella, R.; Su, H.; Mathews, S.; Ahooyi, T.M.; Chen, C.; Mancuso, P.; Sariyer, R.; Ferrante, P.; et al. Sequential LASER ART and CRISPR Treatments Eliminate HIV-1 in a Subset of Infected Humanized Mice. Nat. Commun. 2019, 10, 2753. [CrossRef] [PubMed]

107. Golombek, S.K.; May, J.N.; Theek, B.; Appold, L.; Drude, N.; Kiessling, F.; Lammers, T. Tumor targeting via EPR: Strategies to enhance patient responses. Adv. Drug Deliv. Rev. 2018, 130, 17-38. [CrossRef] [PubMed]

108. Ferrari, M. Cancer nanotechnology: Opportunities and challenges. Nat. Rev. Cancer 2005, 5, $161-171$. [CrossRef]

109. Richter, W.F.; Bhansali, S.G.; Morris, M.E.; Svensson, C.; Balthasar, J.; Theil, F.-P.; Richter, W.F.; Bhansali, S.G.; Morris, M.E. Mechanistic determinants of biotherapeutics absorption following SC administration. AAPS J. 2012, 14, 559-570. [CrossRef]

110. Kinman, L.; Bui, T.; Larsen, K.; Tsai, C.-C.; Anderson, D.; Morton, W.R.; Hu, S.; Ho, R.J.Y. Optimization of Lipid Y Indinavir Complexes for Localization in Lymphoid Tissues of HIV-Infected Macaques. J. Acquir. Immune Defic. Syndr. 2006, 42, 155-161. [CrossRef] 
111. Kinman, L.; Brodie, S.J.; Tsai, C.C.; Bui, T.; Larsen, K.; Schmidt, A.; Anderson, D.; Morton, W.R.; Hu, S.L.; Ho, R.J.Y. Lipid-Drug Association Enhanced HIV-1 Protease Inhibitor Indinavir Localization in Lymphoid Tissues and Viral Load Reduction: A Proof of Concept Study in HIV-2287-Infected Macaques. J. Acquir. Immune Defic. Syndr. 2003, 34, 387-397. [CrossRef]

112. Freeling, J.P.; Ho, R.J.Y. Anti-HIV drug particles may overcome lymphatic drug insufficiency and associated HIV persistence. Proc. Natl. Acad. Sci. USA 2014, 111, E2512-E2513. [CrossRef]

113. Freeling, J.P.; Koehn, J.; Shu, C.; Sun, J.; Ho, R.J.Y. Anti-HIV Drug-Combination Nanoparticles Enhance Plasma Drug Exposure Duration as Well as Triple-Drug Combination Levels in Cells Within Lymph Nodes and Blood in Primates. AIDS Res. Hum. Retrovir. 2015, 31, 107-114. [CrossRef]

114. Kraft, J.C.; Mcconnachie, L.A.; Koehn, J.; Kinman, L.; Collins, C.; Shen, D.D.; Collier, A.C.; Ho, R.J.Y. Long-acting combination anti-HIV drug suspension enhances and sustains higher drug levels in lymph node cells than in blood cells and plasma. AIDS 2017, 31, 765-770. [CrossRef]

115. Kraft, J.C.; Treuting, P.M.; Ho, R.J.Y. Indocyanine green nanoparticles undergo selective lymphatic uptake, distribution and retention and enable detailed mapping of lymph vessels, nodes and abnormalities. J. Drug Target. 2018, 26, 494-504. [CrossRef] [PubMed]

116. Kraft, J.C.; McConnachie, L.A.; Koehn, J.; Kinman, L.; Sun, J.; Collier, A.C.; Collins, C.; Shen, D.D.; Ho, R.J.Y. Mechanism-based pharmacokinetic (MBPK) models describe the complex plasma kinetics of three antiretrovirals delivered by a long-acting anti-HIV drug combination nanoparticle formulation. J. Control. Release 2018, 275, 229-241. [CrossRef] [PubMed]

117. Glass, J.J.; Yuen, D.; Rae, J.; Johnston, A.P.R.; Parton, R.G.; Kent, S.J.; De Rose, R. Human immune cell targeting of protein nanoparticles-caveospheres. Nanoscale 2016, 8, 8255-8265. [CrossRef] [PubMed]

118. Yang, S.; Chen, Y.; Kaien, G.; Dash, A.; Sayre, C.L.; Davies, N.M.; Ho, E.A. Novel intravaginal nanomedicine for the targeted delivery of saquinavir to CD + immune cells. Int. J. Nanomed. 2013, 8, 2847-2858.

119. Ramana, L.N.; Sharma, S.; Sethuraman, S.; Ranga, U.; Krishnan, U.M. Stealth anti-CD4 conjugated immunoliposomes with dual antiretroviral drugs-Modern Trojan horses to combat HIV. Eur. J. Pharm. Biopharm. 2015, 89, 300-311. [CrossRef] [PubMed]

120. Kovochich, M.; Marsden, M.D.; Zack, J.A. Activation of Latent HIV Using Drug-Loaded Nanoparticles. PLoS ONE 2011, 6, e18270. [CrossRef]

121. Endsley, A.N.; Ho, R.J.Y. Enhanced anti-HIV efficacy of indinavir after inclusion in CD4-targeted lipid nanoparticles. J. Acquir. Immune Defic. Syndr. 2012, 61, 417-424. [CrossRef]

122. Endsley, A.N.; Ho, R.J.Y. Design and characterization of novel peptide-coated lipid nanoparticles for targeting anti-HIV drug to CD4 expressing cells. AAPS J. 2012, 14, 225-235. [CrossRef]

123. Pelchen-Matthews, A.; Clapham, P.; Marsh, M. Role of CD4 endocytosis in human immunodeficiency virus infection. J. Virol. 1995, 69, 8164-8168. [CrossRef]

124. Pelchen-Matthews, A.; Armes, J.E.; Griffiths, G.; Marsh, M. Differential endocytosis of CD4 in lymphocytic and nonlymphocytic cells. J. Exp. Med. 1991, 173, 575-587. [CrossRef] [PubMed]

125. Pollock, S.; Dwek, R.A.; Burton, D.R.; Zitzmann, N. N-Butyldeoxynojirimycin is a broadly effective anti-HIV therapy significantly enhanced by targeted liposome delivery. AIDS 2008, 22, 1961-1969. [CrossRef] [PubMed]

126. Descours, B.; Petitjean, G.; López-Zaragoza, J.-L.; Bruel, T.; Raffel, R.; Psomas, C.; Reynes, J.; Lacabaratz, C.; Levy, Y.; Schwartz, O.; et al. CD32a is a marker of a CD4 T-cell HIV reservoir harbouring replication-competent proviruses. Nature 2017, 543, 564-567. [CrossRef] [PubMed]

127. Darcis, G.; Kootstra, N.A.; Hooibrink, B.; van Montfort, T.; Maurer, I.; Groen, K.; Jurriaans, S.; Bakker, M.; van Lint, C.; Berkhout, B.; et al. CD32+CD4+ T Cells Are Highly Enriched for HIV DNA and Can Support Transcriptional Latency. Cell Rep. 2020, 30, 2284-2296. [CrossRef]

128. Bertagnolli, L.N.; White, J.A.; Simonetti, F.R.; Beg, S.A.; Lai, J.; Tomescu, C.; Murray, A.J.; Antar, A.A.R.; Zhang, H.; Margolick, J.B.; et al. The role of CD32 during HIV-1 infection. Nature 2018, 561, E17-E19. [CrossRef]

129. Osuna, C.E.; Lim, S.Y.; Kublin, J.L.; Apps, R.; Chen, E.; Mota, T.M.; Huang, S.H.; Ren, Y.; Bachtel, N.D.; Tsibris, A.M.; et al. Evidence that CD32a does not mark the HIV-1 latent reservoir. Nature 2018, 561, E20-E28. [CrossRef] 
130. Pérez, L.; Anderson, J.; Chipman, J.; Thorkelson, A.; Chun, T.W.; Moir, S.; Haase, A.T.; Douek, D.C.; Schacker, T.W.; Boritz, E.A. Conflicting evidence for HIV enrichment in CD32 + CD4 T cells. Nature 2018, 561, E9-E16. [CrossRef]

131. Abdel-Mohsen, M.; Kuri-Cervantes, L.; Grau-Exposito, J.; Spivak, A.M.; Nell, R.A.; Tomescu, C.; Vadrevu, S.K.; Giron, L.B.; Serra-Peinado, C.; Genescà, M.; et al. CD32 is expressed on cells with transcriptionally active HIV but does not enrich for HIV DNA in resting T cells. Sci. Transl. Med. 2018, 10, eaar6759. [CrossRef]

132. Martin, G.E.; Pace, M.; Thornhill, J.P.; Phetsouphanh, C.; Meyerowitz, J.; Gossez, M.; Brown, H.; Olejniczak, N.; Lwanga, J.; Ramjee, G.; et al. CD32-expressing CD4 T cells are phenotypically diverse and can contain proviral HIV DNA. Front. Immunol. 2018, 9, 928. [CrossRef]

133. Prator, C.A.; Thanh, C.; Kumar, S.; Pan, T.; Peluso, M.J.; Bosch, R.; Jones, N.; Milush, J.M.; Bakkour, S.; Stone, M.; et al. Circulating CD30+ CD4+ T Cells Increase Prior to HIV Rebound Following Analytical Antiretroviral Treatment Interruption. J. Infect. Dis. 2019, 221, 1146-1155. [CrossRef]

134. Wang, C.C.; Thanh, C.; Gibson, E.A.; Ball-Burack, M.; Hogan, L.E.; Descours, B.; Jones, N.; Carvidi, A.B.; Munter, S.; Bakkour, S.; et al. Transient loss of detectable HIV-1 RNA following brentuximab vedotin anti-CD30 therapy for Hodgkin lymphoma. Blood Adv. 2018, 2, 3479-3482. [CrossRef] [PubMed]

135. Rasmussen, T.A.; Lewin, S.R. Shocking HIV out of hiding: Where are we with clinical trials of latency reversing agents? Curr. Opin. HIV AIDS 2016, 11, 394-401. [CrossRef] [PubMed]

136. Jayant, R.D.; Atluri, V.S.R.; Agudelo, M.; Sagar, V.; Kaushik, A.; Nair, M. Sustained-release nanoART formulation for the treatment of neuroAIDS. Int. J. Nanomed. 2015, 10, 1077-1093. [CrossRef] [PubMed]

137. Tang, X.; Liang, Y.; Liu, X.; Zhou, S.; Liu, L.; Zhang, F.; Xie, C.; Cai, S.; Wei, J.; Zhu, Y.; et al. PLGA-PEG Nanoparticles Coated with Anti-CD45RO and Loaded with HDAC Plus Protease Inhibitors Activate Latent HIV and Inhibit Viral Spread. Nanoscale Res. Lett. 2015, 10, 413. [CrossRef] [PubMed]

138. Lino, C.A.; Harper, J.C.; Carney, J.P.; Timlin, J.A. Delivering crispr: A review of the challenges and approaches. Drug Deliv. 2018, 25, 1234-1257. [CrossRef]

(C) 2020 by the authors. Licensee MDPI, Basel, Switzerland. This article is an open access article distributed under the terms and conditions of the Creative Commons Attribution (CC BY) license (http://creativecommons.org/licenses/by/4.0/). 